\title{
Pertumbuhan dan Kadar Albumin Ikan Gabus (Channa striata) yang Diberi Pakan Keong Mas dengan Dosis Berbeda
}

\section{The Growth and Albumine Content of Snake Head Fish (Channa striata) Fed with Different Dose of Apple Snail}

\author{
Sulastri Ilyas ${ }^{1 / 2) *}$, Agus Kurnia ${ }^{3)}$, Muhaimin Hamzah ${ }^{3)}$ \\ 1) Program Studi Ilmu Perikanan PPs Univ. Halu Oleo, Kendari, Indonesia \\ ${ }^{2)}$ Dinas Perikanan Kabupaten Konawe, Indonesia \\ ${ }^{3)}$ Fak. Perikanan dan Ilmu Kelautan Universitas Halu Oleo, Kendari, Indonesia \\ Corresponding autor ${ }^{*}$ : sulastri.dkp@gmail.com
}

\begin{abstract}
This study aimed to determine the optimum dose of apple snail to improve the growth and albumin content of snake head fish. The fish were reared in 9 plastic container (diameter of $50 \mathrm{~cm}$ and height $55 \mathrm{~cm}$ ). All container were filled with freshwater $10 \mathrm{~L}$ in each container filled with 5 fish (initial weight : 32,3 $\pm 1,7 \mathrm{~g}$ ). Three doses of apple snail : $10 \%$ of fish biomassa (treatment A), $15 \%$ of fish biomassa (treatment B) and $20 \%$ of fish biomassa (treatment C) fed to the fish for 45 days of rearing. The fish fed with apple snail in three times a day (08.00, 12.00 and 16.00). The results showed that the fish fed with different dosage of apple snail were not significantly different in weight gain, spesific growth rate (SGR), feed conversion ratio (FCR) feed eficiency (FE) and survival rate (SR) of snake head fish. The weight gain of fish was ranged between 19.55 $\pm 1.78-25.60 \pm 2.10 \mathrm{~g}$, SGR of fish was ranged between $1.05-2.23 \%$, FCR of fish was ranged $4.3-6.19$, FE of fish was ranged between $16.58-23.30 \%$. The highest of feed consumption was found fish fed with $15 \%$ and $20 \%$ of apple snail. While, the highest of albumin content was found in the fish fed with $15 \%$ of apple snail dosage.
\end{abstract}

Keywords : growth, albumin, snake head fish, Channa striata, apple snail

\begin{abstract}
ABSTRAK
Penelitian ini bertujuan untuk menentukan dosis pakan keong mas yang tepat yang mampu meningkatkan pertumbuhan dan kadar albumin ikan gabus. Wadah yang digunakan adalah tong air yang berdiameter $50 \mathrm{~cm}$ dan tinggi $55 \mathrm{~cm}$ sebanyak 9 buah. Masing-masing wadah diisi air sebanyak $10 \mathrm{~L}$ kemudian setiap wadah dimasukkan benih ikan gabus dengan bobot awal 32,3 $\pm 1,7 \mathrm{~g}$ dengan padat tebar 5 ekor/wadah. Pakan diberikan sebanyak 3 kali sehari, yakni pukul $08.00,12.00$ dan 16.00. Penelitian didesain dengan menggunakan rancangan acak lengkap dengan tiga perlakuan dan tiga ulangan. Perlakuan yang diterapkan adalah A : $10 \%$ dari bobot biomasa (BBM) ikan, perlakuan B : 15\% dari BBM dan, perlakuan C : 20\% dari BBM diberikan pada ikan gabus selama 45 hari pemeliharaan. Hasil penelitian menunjukkan bahwa pemberian pakan keong mas dengan dosis berbeda memberikan pengaruh yang sama terhadap pertumbuhan mutlak rata-rata, laju pertumbuhan spesifik, rasio konversi pakan, efisiensi pakan, dan kelangsungan hidup ikan gabus, tetapi memberikan pengaruh yang berbeda terhadap konsumsi pakan dan kadar albumin daging ikan gabus. Pertumbuhan mutlak rata-rata pada penelitian ini berkisar 19,55 $\pm 1,78-25,60 \pm 2,10 \mathrm{~g}$, laju pertumbuhan spesifik berkisar 1,05-2,23\%, rasio konversi pakan berkisar 4,3-6,19, efisiensi pakan berkisar 16,58-23,30\%. Konsumsi pakan tertinggi didapatkan pada perlakuan $\mathrm{B}$ dan $\mathrm{C}$, sedangkan kadar albumin daging tertinggi didapatkan pada pemberian pakan keong mas dosis $15 \%$.
\end{abstract}

Kata kunci : pertumbuhan, albumin, ikan gabus, Channa striata, keong mas

DOI: http://dx.doi.org/10.33772/jspi.v2n1. 


\section{PENDAHULUAN}

Ikan gabus (Channastriata) merupakan jenis ikan air tawar yang banyak dijumpai di perairan umum. Habitat ikangabus adalah di muara sungai, danau, rawa, sawah bahkan dapat hidup di perairan yang kandungan oksigennya rendah. Ikan gabus termasukjenis ikan bernilai ekonomis karena memiliki banyak manfaat. Dalam dunia kedokteran, ikan gabus dikenal manfaatnya dapat mempercepat proses penyembuhan luka pasca operasi. Hal ini dikarenakan tingginya kandungan albumin pada ikan gabus.

Kandungan albumin ikan gabus mempunyai banyak gugus sulfhidril (-SH) yang dapat berfungsi sebagai pengikat radikal, dan adanya gugus tiolini. Albumin dapat berfungsi sebagai antioksidan. Albumin terlibat dalam pembersihan radikal bebas oksigen yang diimplikasikan dalam pathogenesis inflamasi. Larutan fisiologis albumin manusia telah diperlihatkan menghambat produksi radikal bebas oleh leukosit polimorfonuklear. Kemampuan pengikat ini berhubungan dengan melimpahnya gugussulfhidril (-SH) dalam albumin (Sunatrio, 2003).

Albumin selama ini masih dihasilkan atau diperoleh dari darah manusia sehingga harganya cukup mahal dan sangat langkah untuk diperoleh. Berdasarkan penelitian Arisanti (2017) telah menemukan ekstrak albumin dari ikan gabus sehingga kemudian dijadikan alternative untuk mendapatkan albumin yang lebih murah. Albumin merupakan protein utama dalam plasma manusia dan menyusun sekitar $60 \%$ dari total protein plasma. Hati menghasilkan $12 \mathrm{~g}$ albumin perhari yang merupakan $25 \%$ dari total sintesis protein hepatic dan separuh dari seluruh protein yang disekresikan organ. Sebagai sumber bahan makanan yang mengandung protein dan albumin, ikan gabus diperlukan dalam jumlah yang banyak dan kebutuhan akan filtrat albumin di rumah sakit yang semakin meningkat.

Tingginya permintaan dan pemenuhan bahan bakuuntuk albumin yang berasal dari ikan gabus selama ini masih diperoleh dari hasil tangkapan di alam, akan tetapi penangkapan yang dilakukan secara eksploitasi atau secara terus menerus menyebabkan terjadinya penurunan populasi ikan yang ada di alam. Berdasarkan penelitian Jubaedahet al. (2010) menyatakan bahwa penangkapan ikan gabus yang dilakukan secara terus menerus di perairan rawa banjiran menunjukkan terjadinya penurunan potensi reproduksi ikan gabus. Untuk mengatasi hal tersebut perlu adanya kegiatan domestikasi dan budidaya ikan gabus.

Menurut Alimuddin danWiyono (2005), salah satu alternatif untuk membantu pememenuhan pasokan di alam adalah dengan akuakultur (budidaya perikanan) yang harus diawali dengan usaha domestikasi. Selanjutnya hasil penelitianYulisman et al. (2011) menunjukkan bahwa ikan gabus yang dipelihara dalam akuarium dapat hidup dan tumbuh dengan memanfaatkan pakan buatan (pellet komersial). Hal ini menunjukkan bahwa pada prinsipnya ikan gabus berpotensi untuk dibudidayakan. Dalam kegiatan budidaya ikan, pakan memiliki peranan penting untuk peningkatan produksi. Permasalahan yang sering dihadapi dalam budidaya ikan adalah penyediaan pakan buatan yang dapat mendukung dan meningkatkan pertumbuhan dan efisiensi pakan ikan gabus.

Akan tetapi permasalahan yang terjadi dalam pembudidaya ikan adalah penyediaan pakan dimana harga pakan yang mahal serta dibutuhkan jumlahpakan yang banyak sehingga biaya produksi cukup tinggi. Harga pakan ikan yang relative mahal ini disebabkan oleh komposisi utama pada pakan ikanyaitu protein berasal dari tepung ikan yang ketersediaanya masih diimpor, maka diperlukan inovatif dan alternative bahan pakan alami dengan harga relative murah, tersedia terus menerus, mudah diperoleh, bertahan lama dan mengandung protein yang tinggi. Salah satu bahan yang memiliki kandungan protein yang cukup tinggi adalahmkeong mas.

Keong mas merupakan hama bagi tanaman padi, tetapi mengandung protein yang tinggi yang hamper setara dengan kandungan protein tepung ikan. Menurut Suktikno (2011), keong mas mempunyai kandungan protein sekitar 57,67\%, selanjutnya Haslianti $d k k$. (2016) menyatakan bahwa keong mas mempunyai kandungan protein sebesar 38,06\%. Dengan demikian maka keong mas dapat dijadikan sebagai pakan untuk menggantikan pakan ikangabus yang relative murah. Berdasarkan permasalahan diatas, dilakukan penelitian untuk mengetahui pengaruh pertumbuhan dan kadar albumin ikan gabus yang diberipakan keong mas dengan dosis berbeda. Penelitian ini bertujuan untuk menentukan dosis pakan keong mas yang tepat yang mampu meningkatkan pertumbuhan dan kadar albumin ikan gabus. 
62 Sulastri Ilyas et al.

JURNAL SAINS dan INOVASI PERIKANAN / Journal of Fishery Science and Innovation

Vol. 2, No. 2, 60-68, Juli 2018

\section{METODE PENELITIAN}

Penelitian ini dilaksanakan selama 45 hari yaitu dari bulan Agustus sampai September 2017. Pemeliharanan ikan uji dilakukan di Laboratorium Pembenihan dan Produksi Fakultas Perikanan dan Ilmu Kelautan (FPIK) Universitas Halu Oleo Kendari. Analisa proksimat dan kadar albumin ikan gabus dilaksanakan di Laboratorium Biologi Fakultas Matematika dan Ilmu Pengetahuan Alam (MIPA) Universitas Halu Oleo sedangkan analisa kualitas air dilaksanakan di Laboratorium Pengujian Fakultas Perikanan dan Ilmu Kelautan Universitas Halu Oleo.

Penelitian ini menggunakan Rancangan Acak Lengkap (RAL) dengan 3 taraf perlakuan (Perlakuan $\mathrm{A}=$ pakan keong mas dengan dosis $10 \%$ per bobot tubuh per hari; perlakuan $\mathrm{B}=$ pakan keong mas dengan dosis $15 \%$ per bobot tubuh per hari; perlakuan $\mathrm{C}$ pakan keong mas dengan dosis $20 \%$ per bobot tubuh per hari) dan 3 kali ulangan.

Wadah yang digunakan adalah tong air yang berdiameter $50 \mathrm{~cm}$ dan tinggi $55 \mathrm{~cm}$ sebanyak 9 buah yang telah dibersihkan. Masing-masing wadah diisi air sebanyak $10 \mathrm{~L}$ kemudian setiap wadah masukan benih ikan gabus dengan ukuran panjang $\pm 10 \mathrm{~cm}$ dengan padat tebar 5 ekor/wadah.

Sebelum dilakukan uji coba, ikan diaklimatisasi terlebih dahulu selama seminggu dengan lingkungan yang baru dan pakan yang diberikan. Keong mas yang diperoleh terlebih dahulu dicuci bersih dan dikeluarkan dari cangkangnya dengan cara memecahkan cangkang. Daging dan jeroannya dipisahkan,selanjutnya daging yang diperoleh direndam dengan air garam selama 30 menit untuk membersihkan lendir dan menetralkan sifat asamnya. Daging dicincang sesuai dengan ukuran mulut ikan, selanjutnya disimpan dalam lemari es, sebelum diberikan pada ikan. Pada suhu yang tinggi kandungan protein akan rusak sehingga nilai gizinya turun, oleh karena itu hanya digunakan suhu maksimal $60^{\circ} \mathrm{C}$ (Firdus, 2004).

Setelah ikan gabus dipastikan telah beradaptasi, ikan uji dipuasakan selama 24 jam kemudian diukur panjang dan ditimbang bobotnya. Pemeliharaan hewan uji dilakukan selama dua bulan. Penimbangan bobot dilakukan sebanyak 4 kali, yakni pada hari ke-0 (awal penelitian), hari ke-15, hari ke-30 dan hari ke-45 (akhir penelitian). Selama pemeliharaan, ikan uji diberi pakan dengan dosis pemberian pakan sebanyak $10 \%, 15 \%$, dan $20 \%$ dari biomassa setiap hari. Frekuensi pemberian pakan sebanyak 3 kali, yakni pukul 08.00, 12.00 dan 16.00 WITA. Pengukuran kadar albumin dilakukan pada awal dan akhir penelitian dengan mengambil sampel daging ikan gabus. Beberapa parameter yang diukur meliputi:

\section{Pertumbuhan Mutlak (PM)}

Pertumbuhan mutlak (PM) ikan uji berdasarkan bobot tubuh digunakan rumus $\mathrm{Hu}$ et al. (2008):

$$
\mathrm{PM}=\mathrm{Wt}-\mathrm{W}_{0}
$$

Keterangan :

$\mathrm{PM}=$ Pertumbuhan mutlak rata-rata $(\mathrm{g})$

$\mathrm{Wt}=$ Bobot rata-rata ikan pada waktu $\mathrm{t}(\mathrm{g})$

$\mathrm{W}_{0}=$ Bobot rata-rata ikan pada awal penelitian $(\mathrm{g})$

\section{Laju Pertumbuhan Spesifik (LPS)}

Laju pertumbuhan spesifik (LPS) diukur setiap selang waktu 15 hari sekali selama 45 hari berdasarkan bobot tubuh menggunakan rumus $\mathrm{Hu}$ et al. (2008) berikut :

$$
\begin{aligned}
& L P S=\frac{\operatorname{Ln} W_{t}-\operatorname{Ln} W_{0}}{t} \times 100 \% \\
& \text { Keterangan : LPS }=\text { Laju Pertumbuhan } \\
& \text { Spesifik }(\%) \\
& \mathrm{W}_{\mathrm{t}}=\text { Bobot rata-rata ikan pada } \\
& \text { waktu t (g) } \\
& \mathrm{W}_{0}=\text { Bobot rata-rata ikan pada } \\
& \text { awal penelitian }(\mathrm{g}) \\
& \mathrm{t}=\text { Periode waktu (hari) }
\end{aligned}
$$

\section{Konsumsi Pakan}

Konsumsi pakan harian diketahui dengan menghitung selisih antara bobot pakan yang diberi dan bobot pakan sisa (Bores et al., 2006).

\section{Rasio Konversi Pakan (FCR)}

Rasio konversi pakan (FCR) hewanujidihitung dengan menggunakan rumus yang digunakan Watanabe (1988), yaitu:

$$
F C R=\frac{F}{W t-W o}
$$

Dimana :

$\mathrm{FCR}=$ Rasio konversi pakan

$\mathrm{F} \quad=$ Jumlah pakan yang dikonsumsi

$\mathrm{Wt}=$ Bobot akhir rata-rata

$\mathrm{Wo}=$ Bobot awal rata-rata

Efisiensi Pakan (EP)

Efisiensipakan

dihitungdenganmenggunakanrumus yang digunakan Watanabe (1988), yaitu:

$$
E P=\frac{1}{F C R} x 100 \%
$$

Dimana :

EP = Efisiensi pakan

FCR = Rasio Konversi pakan

\section{Kelangsungan Hidup (SR)}

Kelangsungan hidup (SR) dihitung berdasarkan persamaan Zonneveld et al. (1991):

Dimana :

$$
S R=\frac{N t}{N o} \times 100 \%
$$

$\mathrm{SR}=$ Persentasi Kelangsungan Hidup

$\mathrm{Nt}=$ Jumlah ikan yang hidup di akhir penelitian 
No = Jumlah ikan yang hidup di awal penelitian

Data pertumbuhan mutlak rata-rata, laju pertumbuhan spesifik, konsumsi pakan, konversi pakan, efesiensi pakan, kelangsungan hidup, dan kadar albumin dianalisis dengan menggunakan analisis ragam dengan bantuan program SPSS 16.0. Data kualitas air dianalisis secara deskriptif

\section{HASIL DAN PEMBAHASAN}

\section{Pertumbuhan Mutlak Rata-rata}

Hasil perhitungan pertumbuhan mutlak rata-rata ikan gabus selama penelitian disajikan pada Gambar 1.

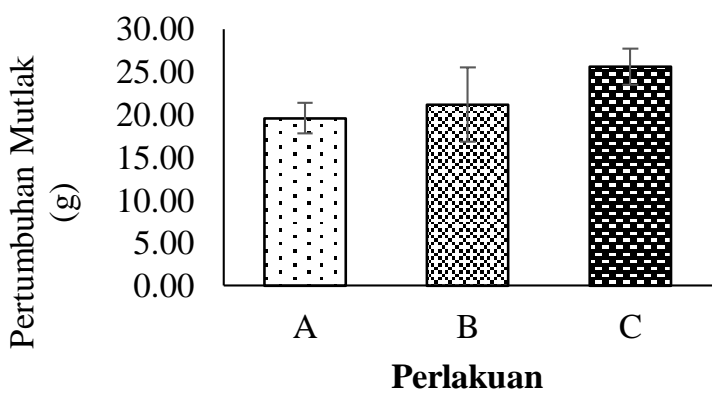

Gambar 1. Pertumbuhan mutlak rata-rata ikan gabus $(C$. striata) yang diberi pakan keong mas dengan dosis: A (10\% dari bobot tubuh); B (15\% dari bobot tubuh); dan C (20\% dari bobot tubuh).

Pada Gambar 1 terlihat bahwa pertumbuhan mutlak rata-rata tertinggi didapatkan pada kelompok ikan yang

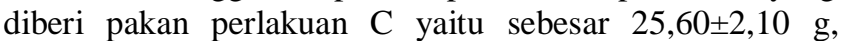

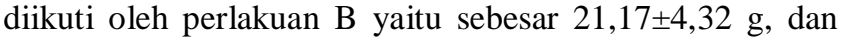
terendah didapatkan pada perlakuan A yaitu sebesar $19,55 \pm 1,78$ g. Hasil analisis ragam menunjukkan bahwa perlakuan dosis keong mas tidak memberikan pengaruh yang berbeda nyata terhadap pertumbuhan mutlak rata-rata ikan gabus.

\section{Laju Pertumbuhan Spesifik (LPS)}

Hasil perhitungan laju pertumbuhan spesifik ikan gabus selama penelitian disajikan pada Gambar 2. Pada Gambar 2 terlihat bahwa laju pertumbuhan spesifik tertinggi pada hari ke-15 didapatkan pada kelompok ikan yang diberi pakan perlakuan $\mathrm{B}$ dan $\mathrm{C}$ masing-masing sebesar 2,23\% dan terendah didapatkan pada perlakuan A sebesar $1,71 \%$. Pada hari ke-30, laju pertumbuhan spesifik tertinggi didapatkan pada kelompok ikan yang diberi pakan perlakuan $\mathrm{C}$ yaitu sebesar $1,60 \%$, diikuti oleh perlakuan $\mathrm{B}$ yaitu sebesar $1,40 \%$, dan terendah didapatkan pada perlakuan A yaitu sebesar 1,44\%. Pada hari ke-45, laju pertumbuhan spesifik tertinggi didapatkan pada kelompok ikan yang diberi pakan perlakuan $\mathrm{C}$ yaitu sebesar $1,30 \%$, diikuti oleh perlakuan $\mathrm{B}$ yaitu sebesar $1,12 \%$, dan terendah didapatkan pada perlakuan A yaitu sebesar 1,05\%. Hasil analisis ragam menunjukkan bahwa perbedaan dosis pakan keong mas tidak memberikan pengaruh yang berbeda nyata terhadap laju pertumbuhan spesifik ikan gabus ( $C$. striata) pada hari ke-15, 30 dan 45.

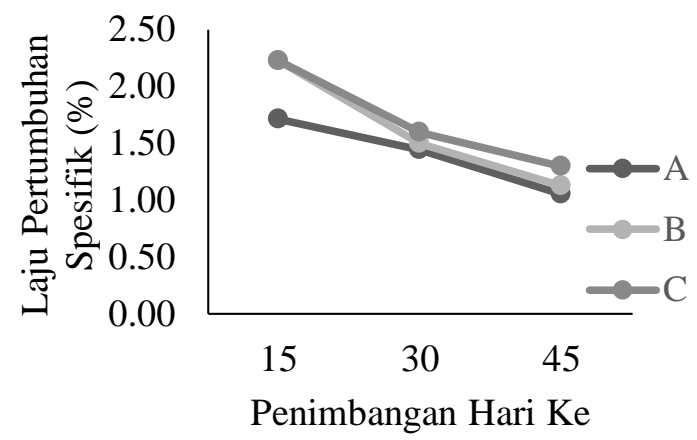

Gambar 2. Laju pertumbuhan spesifik ikan gabus ( $C$. striata) yang diberi pakan keong mas dengan dosis: A (10\% dari bobot tubuh); B (15\% dari bobot tubuh); dan C (20\% dari bobot tubuh).

\section{Konsumsi Pakan}

Hasil perhitungan konsumsi pakan rata-rata ikan gabus selama penelitian disajikan pada Gambar 3 .

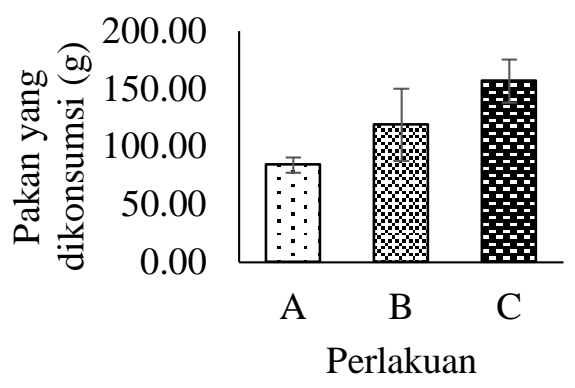

Gambar 3. Konsumsi pakan ikan gabus (C. striata) selama penelitian dengan pemberian pakan keong mas dengan dosis: A (10\% dari bobot tubuh); B (15\% dari bobot tubuh); dan C (20\% dari bobot tubuh).

Pada Gambar 3 terlihat bahwa konsumsi pakan ikan gabus tertinggi didapatkan pada kelompok ikan yang diberi pakan perlakuan $\mathrm{C}$ yaitu sebesar 156,68 g, diikuti oleh perlakuan B sebesar 118,82 g, dan terendah didapatkan pada perlakuan A yaitu sebesar 82,24 g. Hasil analisis ragam menunjukkan bahwa perbedaan dosis keong mas memberikan pengaruh yang berbeda nyata terhadap konsumsi pakan ikan gabus.

\section{Rasio Konversi Pakan (FCR)}

Hasil perhitungan rasio konversi pakan ikan gabus selama penelitian disajikan pada Gambar 4. 
64 Sulastri Ilyas et al.

JURNAL SAINS dan INOVASI PERIKANAN / Journal of Fishery Science and Innovation

Vol. 2, No. 2, 60-68, Juli 2018

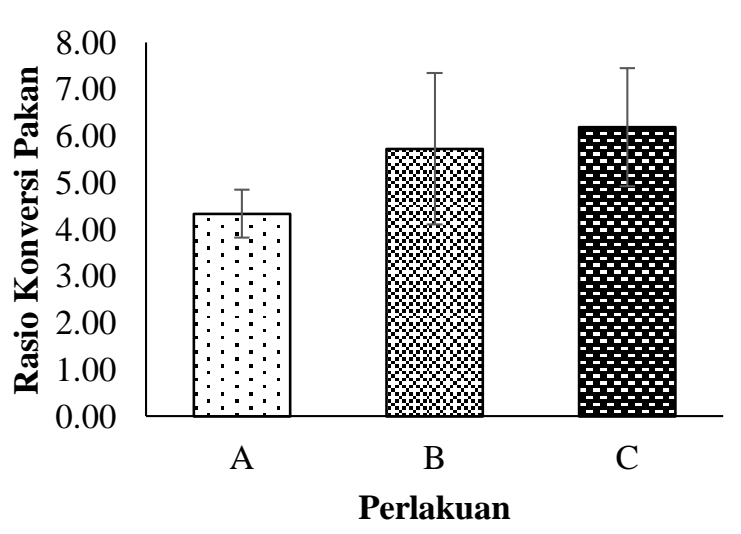

Gambar 4. Rasio konversi pakan ikan gabus (C. striata) yang diberi pakan keong mas dengan dosis: A (10\% dari bobot tubuh); B (15\% dari bobot tubuh); dan C (20\% dari bobot tubuh).

Pada Gambar 4 terlihat bahwa rasio konversi pakan terendah didapatkan pada kelompok ikan yang diberi pakan perlakuan A yaitu sebesar 4,3, diikuti oleh perlakuan B sebesar 5,72, dan tertinggi didapatkan pada perlakuan $\mathrm{C}$ yaitu sebesar 6,19. Hasil analisis ragam menunjukkan bahwa perbedaan dosis keong mas tidak memberikan pengaruh yang berbeda nyata terhadap rasio konversi pakan ikan gabus.

\section{Efisiensi Pakan (EP)}

Hasil perhitungan efisiensi pakan ikan gabus selama penelitian disajikan pada Gambar 5.

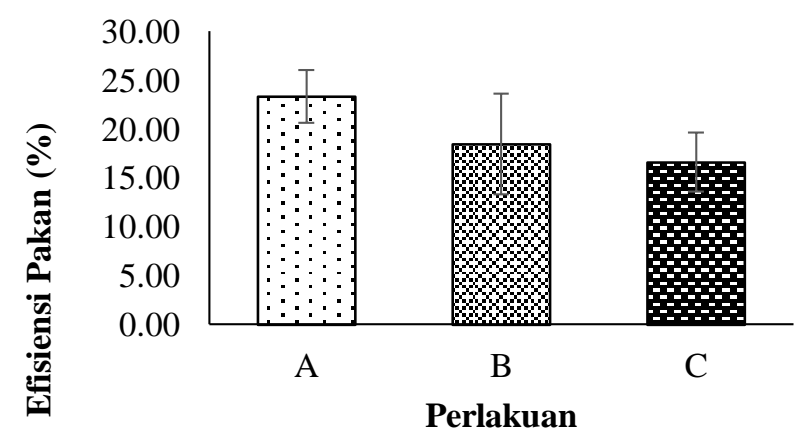

Gambar 5. Efisiensi pakan ikan gabus (C. striata) yang diberi pakan keong mas dengan dosis: A (10\% dari bobot tubuh); B (15\% dari bobot tubuh); dan C (20\% dari bobot tubuh).

Pada Gambar 5 terlihat bahwa efisiensi pakan tertinggi didapatkan pada kelompok ikan gabus yang diberi pakan perlakuan A yaitu sebesar $23,30 \%$, diikuti oleh perlakuan B yaitu sebesar $18,43 \%$, dan terendah didapatkan pada perlakuan C yaitu sebesar $16,58 \%$. Hasil analisis ragam menunjukkan bahwa perbedaan dosis keong mas tidak memberikan pengaruh yang berbeda nyata terhadap efisiensi pakan ikan gabus.

\section{Kelangsungan Hidup (SR)}

Hasil perhitungan kelangsungan hidup ikan gabus selama penelitian disajikan pada Gambar 6.

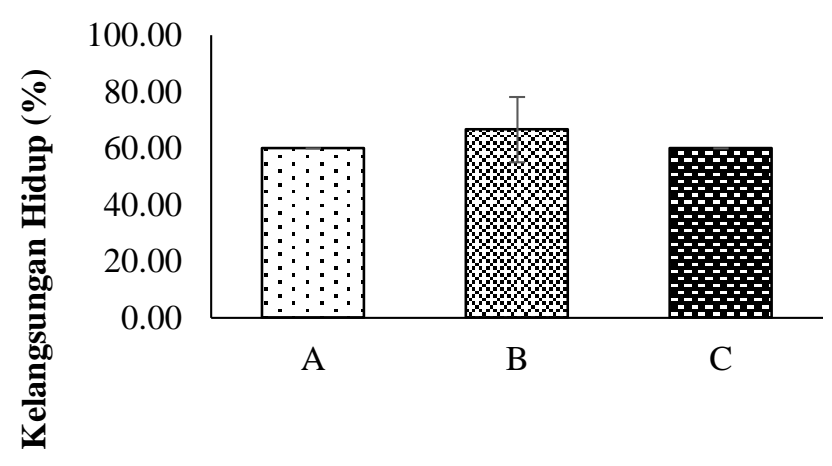

Perlakuan

Gambar 6. Kelangsungan hidup ikan gabus (C. striata) yang diberi pakan keong mas dengan dosis: A (10\% dari bobot tubuh); B (15\% dari bobot tubuh); dan C (20\% dari bobot tubuh).

Pada Gambar 6 terlihat bahwa kelangsungan hidup tertinggi didapatkan pada kelompok ikan yang diberi pakan perlakuan B yaitu sebesar $60,67 \%$ dan terendah didapatkan pada perlakuan A dan B dengan kelangsungan hidup yang sama yaitu $60,00 \%$. Hasil analisis ragam menunjukkan bahwa perlakuan dosis keong mas tidak memberikan pengaruh yang berbeda nyata terhadap kelangsungan hidup ikan gabus.

\section{Kandungan Albumin}

Hasil perhitungan kadar albumin daging ikan gabus selama penelitian disajikan pada Gambar 7.

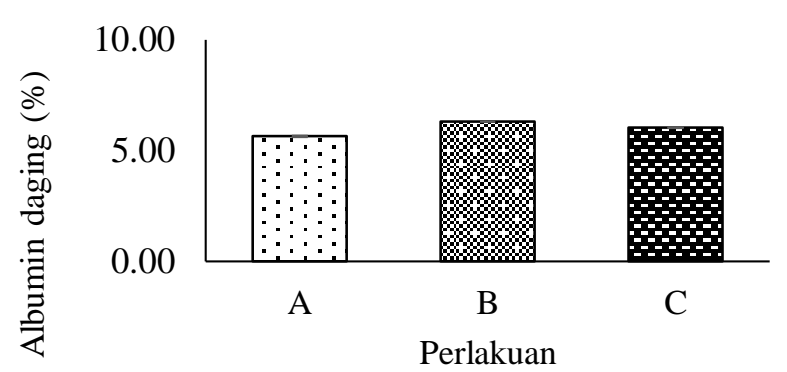

Gambar 7. Kadar albumin daging ikan gabus (C. striata) yang diberi pakan keong mas dengan dosis: A (10\% dari bobot tubuh); B (15\% dari bobot tubuh); dan C (20\% dari bobot tubuh). 
Pada Gambar 7 terlihat bahwa kadar albumin tertinggi didapatkan pada kelompok ikan yang diberi pakan perlakuan B yaitu sebesar 6,29\%, diikuti oleh perlakuan C yaitu sebesar $6,02 \%$, dan terendah didapatkan pada perlakuan A yaitu sebesar 5,64\%. Hasil analisis ragam menunjukkan bahwa perlakuan dosis keong mas memberikan pengaruh yang berbeda nyata terhadap kadar albumin daging ikan gabus.

\section{Kualitas Air}

Hasil pengukuran parameter kualitas air selama penelitian disajikan pada Tabel 1.

Tabel 1. Parameter kualitas air selama penelitian

\begin{tabular}{clc}
\hline No. & Parameter & Nilai \\
\hline 1. & Suhu & $23-26,1^{\circ} \mathrm{C}$ \\
2. & pH & $7,0-8,0$ \\
3. & DO & $4,5-7,5 \mathrm{mg} .1^{-1}$ \\
\hline
\end{tabular}

\section{Pembahasan}

Hasil penelitian menunjukkan bahwa pemberian pakan keong mas dengan dosis $10 \%, 15 \%$ ataupun $20 \%$ pada ikan gabus tidak memberikan pengaruh yang berbeda nyata terhadap pertumbuhan mutlak rata-rata dan laju pertumbuhan spesifik ikan gabus. Berdasarkan Gambar 1 dan 2 terlihat bahwa pertumbuhan mutlak rata-rata dan laju pertumbuhan spesifik ikan gabuscenderung semakin tinggi dengan semakin meningkatnya dosis keong mas yang diberikan. Dengan demikian, dapat dikatakan bahwa pemberian pakan keong mas dengan dosis $10 \%$ dari bobot tubuh telah memenuhi kebutuhan ikan gabus untuk pertumbuhannya. Yulisman (2011) menyatakan bahwa benih ikan gabus yang diberi pakan sebanyak 10\% dari bobot tubuh per hari menghasilkan pertumbuhan yang lebih tinggi dibandingkan dengan pemberian pakan 5\%, 15\% dan 20\%. Hal ini didukung pula oleh Augusta (2011) yang mendapatkan bahwa pemberian cincangan bekicot/keong mas sebesar $11 \%$ dapat memberikan pengaruh baik terhadap pertumbuhan ikan gabus.

Sudarman (1988) menyatakan bahwa kecepatan pertumbuhan tergantung pada jumlah pakan yang dikonsumsi dan kemampuan organisme dalam memanfaatkan pakan. Pemberian pakan yang tepat baik kualitas maupun kuantitasnya dapat memberikan pertumbuhan yang optimum bagi ikan (Wyban dan Sweenly, 1991). Wati (2008) menambahkan bahwa semakin rendah nilai rasio konversi pakan maka semakin baik pakan tersebut, karena semakin sedikit jumlah pakan yang dibutuhkan untuk menghasilkan berat tertentu.

Hasil penelitian ini juga menunjukkan bahwa pemberian pakan keong mas dengan dosis 10\%, $15 \%$ ataupun $20 \%$ pada ikan gabus memberikan pengaruh yang berbeda nyata terhadap konsumsi pakan ikan gabus. Peningkatan persentase jumlah pakan yang diberikan memberikan pengaruh yang signifikan terhadap konsumsi pakan ikan gabus dimana makin tinggi dosis pakan keong mas yang diberikan, maka makin tinggi pula konsumsi pakan. Hal ini diduga ikan gabus memakan semua makan yang diberikan karena ikan gabus merupakan ikan predator dan buas sehingga cenderung tidak menyeleksi makanannya. Nelson (1994) menyatakan bahwa ikan gabus merupakan ikan predator dan buas invasif sehingga dapat memakan makanan yang tersedia. Anakotta (2002) menambahkan bahwa ikan gabus memiliki relung makanan yang lebih besar mengindikasikan jenis makanan yang dikonsumsi lebih beragam. Selanjutnya dikatakan bahwa jika ikan memiliki relung lambung yang sempit atau kecil berarti ikan cenderung melakukan seleksi terhadap makanan tertentu. Perbedaan pemberian dosis pakan tidak memberikan dampak yang signifikan terhadap nilai konversi pakan menjadi jaringan/bobot tubuh ikan. Pemberian pakan yang berlebihan selain menyebabkan pemborosan (pakan tidak efisien) juga akan menyebabkan kualitas air akan terganggu (Yulisman, 2011).

Pada penelitian didapatkan bahwa pemberian pakan keong mas dengan dosis $10 \%, 15 \%$ ataupun $20 \%$ pada ikan gabus tidak memberikan pengaruh yang berbeda nyata terhadap rasio konversi pakan ikan gabus. Rasio konversi pakan pada ikan uji dapat dipengaruhi oleh kebutuhan akan nutrisi ikan uji yang terkandung dalam pakan yang diberikan, serta kemampuan cerna pakan oleh ikan uji. Kebutuhan nutrisi ikan yang tidak terpenuhi dalam pakan dapat menyebabkan kekerdilan pada ikan sebab pada dasarnya energi dapat tersimpan menjadi otot pada proses pertumbuhan dapat terjadi jika seluruh jalur pemanfaatan energi telah terpenuhi seperti energi untuk beraktifitas dan energi maintenance. Kemampuan cerna pakan dapat berpengaruh terhadap konversi pakan sebab pakan yang tidak dapat tercerna dengan baik akan sulit terserap dalam saluran pencernaan sehingga asupan nutrisi yang dibutuhkan tidak terpenuhi dan energi yang terkandung dalam pakan akan terbuang melalui feses. Hal ini sesuai dengan Maulidin et al. (2016) yang mengemukakan bahwa kemampuan ikan gabus dalam mengkonversi pakan menjadi jaringan sehingga terdapat penambahan bobot tubuh tidak hanya ditentukan oleh kandungan nutrisi dalam pakan tetapi ditentukan juga oleh tingkat kecernaan pakan tersebut.

Pada penelitian ini juga terlihat bahwa pemberian pakan keong mas dengan dosis 10\%, 15\% ataupun $20 \%$ pada ikan gabus tidak memberikan pengaruh yang berbeda nyata terhadap efisiensi pakan ikan gabus. Nilai efisiensi pakan ditentukan oleh kandungan nutrisi dalam pakan serta daya cerna pakan yang diberikan. Maulidin et al. (2016) menyatakan bahwa rendahnya daya cerna nutrisi dalam pakan berdampak terhadap rendahnya pertumbuhan. Hal tersebut menunjukkan bahwa kandungan nutrisi yang tidak dapat tercerna dan termanfaatkan dengan baik menyebabkan nilai efisiensi pakan menjadi rendah. Hal ini 
66 Sulastri Ilyas et al.

JURNAL SAINS dan INOVASI PERIKANAN / Journal of Fishery Science and Innovation

Vol. 2, No. 2, 60-68, Juli 2018

sejalan dengan Agustin et al. (2014) yang mengemukakan bahwa peningkatan kecernaan pakan dapat membantu proses penyerapan nutrisi yang terkandung dalam bahan pakan sehingga pakan yang dikonsumsi lebih efisien.

Hasil penelitian juga menunjukkan bahwa pemberian pakan keong mas dengan dosis 10\%, 15\% ataupun $20 \%$ pada ikan gabus tidak memberikan pengaruh yang berbeda nyata terhadap kelangsungan hidup ikan gabus. Kelangsungan hidup ikan gabus pada penelitian ini berkisar antara $60,0 \%-66,67 \%$. Kelangsungan hidup ikan uji yang rendah pada penelitian ini disebabkan oleh sifat kanibalisme ikan gabus yang merupakan sifat alami dan diwariskan secara genetik. Hal ini sesuai dengan pernyataan Effendie (2004) bahwa kelangsungan hidup organisme budidaya dapat disebabkan oleh faktor biotik yaitu persaingan, parasit, umur, predator, kepadatan dan penanganan manusia, sedangkan faktor abiotik adalah sifat kimia dan fisika perairan. Sebagaimana kualitas air penelitian ini sesuai untuk kehidupan ikan gabus, baik pada parameter suhu, $\mathrm{pH}$ dan oksigen terlarut.

Pada pengukuran kandungan albumin dalam daging ikan menunjukkan bahwa pemberian keong mas sebanyak $15 \%$ bobot tubuhmengandung albumin tertinggi sebesar $6,29 \%$ selanjutnya pemberian sebanyak $20 \%$ keong mas ke ikan gabus menhgasilkan kandungan albumin sebesar $6,02 \%$ dan pemberian sebanyak $10 \%$ keong mas ke ikan gabus menghasilkan albumin sebesar 5,64\%. Kandungan albumin penelitian ini lebih tinggi bila dibandingkan dengan kadar albumin ikan gabus pada penelitian dilakukan oleh Kusumaningrum et al. (2014) dengan kandungan albumin tertinggi sebesar $1,70 \%$ didapatkan pada pemberian pakan komersil (kadar protein 32\%). Hasil penelitian Suprayitno et al. (2008) menunjukkan bahwa, ikan gabus mengandung $6,2 \%$ albumin. Tingginya kandungan albumin pada penelitian ini diduga pakan hewani merupakan pakan yang baik untuk peningkatan kandungan albumin yang maksimal pada ikan gabus. Dosis pakan keong mas 15\% merupakan titik optimum yang menghasilkan albumin maksimum.

Albumin dalam daging ikan pada hakikatnya adalah sebuah poliribosom yang berikatan dengan organel reticulum endoplasma pada sel hati. Albumin disintesis dalam organ hati sebanyak 100-200 mikro gram per hari, sintesis albumin dipengaruhi oleh tiga faktor utama yaitu jenis asam amino yang masuk ke dalam tubuh melalui makanan yaitu triptofan, arginin, ornitin, lisin, fenilalanin, treonin dan prolin, kemudian pengaruh hormon diantaranya hormon pertumbuhan, insulin, adrenokortikotropik, testosteron dan korteks adrenal serta adanya suatu penyakit yang dapat menyebabkan gangguan sintesis albumin (Permadi et al., 2017).Albumin merupakan protein mayor yang berperan penting dalam transport bahan fisiologis atau metabolit tubuh seperti asam lemak, hormon, bilirubin, dan ligan dari luar maupun sistem regulasi tekanan osmose koloid darah (Kovyrshina \& Rudneva, 2012). Albumin bersifat spesifik antar jenis ikan dan dapat digunakan untuk alat diagnosa yang menggambarkan kesehatan hewan, fungsi hati, status metabolisme dan kondisi stres.

Beberapa faktor yang mempengaruhi kadar albumin adalah nutrisi, lingkungan, hormon dan ada tidaknya suatu penyakit. Asam amino sangat erat peranannya dalam sintesa albumin pada jaringan (Santoso, 2009). Kandungan albumin pada ikan gabus dapat dipengaruhi oleh faktor internal ikan seperti jenis kelamin dan ukuran tubuh (Alfarisy et al., 2003) serta dipengaruhi kondisi lingkungan perairan seperti $\mathrm{pH}, \mathrm{DO}$, suhu dan salinitas (Fuadi et al., 2007).

Kisaran suhu air selama masa penelitian berkisar antara $23-26,1^{\circ} \mathrm{C}$. Kisaran suhu pada penelitian ini masih dalam kisaran toleransi ikan gabus sebagimana diungkapkan oleh Pillay et al. (2005) bahwa ikan gabus memiliki toleransi yang besar terhadap suhu perairan yang berkisar antara $20-35^{\circ} \mathrm{C}$.

Parameter $\mathrm{pH}$ air pada penelitian ini berada pada kisaran 7,0-8,0 juga masih tergolong baik untuk budidaya ikan gabus. Syafei et al. (2005) mengemukakan bahwa ikan gabus yang hidup di perairan umum daerah Jambi berada

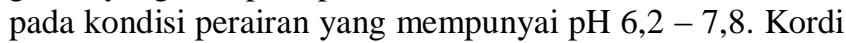
(2011) menambahkan, pH yang baik untuk pemeliharaan benih ikan gabus adalah 6,5-9,0. Apabila pH kurang dari kisaran optimal, maka pertumbuhan ikan akan terhambat dan ikan menjadi sangat sensitif terhadap infeksi patogen.

Oksigen terlarut (DO) dalam penelitian ini adalah 4,5 7,5 $\mathrm{mg} / \mathrm{L}$ tergolong kisaran yang masih dalam toleransi bagi ikan gabus. Schmittou dan Emeritus (2003) mengemukakan bahwa ikan gabus mampu bertahan hidup pada perairan yang oksigen terlarutnya hanya mencapai 3 mg/L.. Kordi (2011) menambahkan bahwa ikan gabus mampu hidup di perairan yang minim oksigen mencapai 2 $\mathrm{mg} /$ Lkarena ikan gabus mempunyai alat pernafasan tambahan yaitu diverticula sehingga mampu mengambil oksigen langsung dari udara dengan menyembulkan mulut ke permukaan air.

\section{KESIMPULAN}

Berdasarkan hasil penelitian dan pembahasan maka dapat disimpulkan bahwa pemberian pakan keong mas dengan dosis berbeda memberikan pengaruh yang sama terhadap pertumbuhan mutlak, laju pertumbuhan spesifik, rasio konversi pakan, efisiensi pakan, dan kelangsungan hidup ikan gabus, tetapi memberikan pengaruh yang berbeda terhadap konsumsi pakan dan kadar albumin daging ikan gabus. Kadar albumin tertinggi didapatkan pada ikan gabus yang diberi pakan keong mas dosis 15\%.

\section{DAFTAR PUSTAKA}

Ademolu KO, Idowu AB, Mafiana CF, Osinowo OA. 2004. Performance, proximate, and mineral analyses of 
African giant land snail (Archachatina marginata) fed different nitrogen sources. African J Biotechnol. 3(8): 412- 417.

Agustin R, Sasanti, AD, Yulisman. 2014. Konversi Pakan, Laju Pertumbuhan, Kelangsungan Hidup dan Populasi Bakteri Benih Ikan Gabus (Channa striata) yang Diberi Pakan dengan Penambahan Probiotik. Jurnal Akuakultur Rawa Indonesia 2(1): 55- 66.

Alfarisy, M.U., N. Abdulgani, Ulfin, I. 2013. Pengaruh Jenis Kelamin dan Ukuran Terhadap Kadar Albumin pada Ikan Gabus (Channa striata). Jurnal Sains dan Seni Pomits 2(1): 1-4.

Allington NI. 2002. Channa striatus. Fish capsule report for biology of fishes. http://www.umich.edu/bio440/fishcapsule96/channa htm.

Anonim. 2002. Budidaya ikan air tawar. Jakarta: Deputi Manegeristik Bidang Pendayagunaan dan Kemasyarakatan IPTEK.

Arisanti D. 2007. Pengendapan albumin ikan gabus (Ophiocephalus striatus) dengan ammonium sulfat [Skripsi]. Malang. Universitas Brawijaya.

Augusto TS. 2011. Pengaruh pemberian pakan tambahan cincangan bekicot dengan prosentase berbeda terhadap pertumbuhan ikan gabus (Channa striata). Fakultas Perikanan Universitas Kristen Palangka Raya . Media Sains 3 (1): 35-37

Bijaksana U. 2004. Ikan-Haruan di perairan rawa Kalimantan Selatan. Makalah pengantar falsafah sains (PPS 702) [Disertasi]. Bogor. Institut Pertanian Bogor.

Chandra S, Banerjee TK. 2004. Histopathological analysis of the respiratory organs of Channa striatasubjected to air exposure. Veterinarski archiv 74:37-52.

Dance PS. 1997. The encyclopedia of sheel. London: Blanford Press

Firdus, Muchlisin ZA. 2005. Pemanfaatan Keong Mas (Pomacea canaliculata) sebagai Pakan Alternatif dalam Budidaya Ikan Kerapu Lumpur (Epinephelus tauvina). Enviro 5 (1):64-66.

Fuadi MH, Santoso A, Syauqi. 2007. Uji Kandungan Albumin Ikan Gabus (Channa striata) dalam Perbedaan Lingkungan Air. Jurnal Ilmiah BIOSAINTROPIS 3(1): 23-30.

Khairuman, Amri K. 2002. Buku Pintar Budidaya 15 Ikan Komsumsi. Jakarta: Agromedia.

Kottelat M, Whitten AJ, Kartikasari SN, Wirjoatmodjo S. 1993. Ikan air tawar indonesia bagian barat dan Sulawesi. Edisi dwi bahasa (Inggris Indonesia). Periplus Edition (HK) Ltd. Jakarta. Bekerja sama dengan proyek EMDI kantor Menteri Negara KLH Repoblik Indonesia.

Kordi MGH. 2011. Panduan Lengkap Bisnis dan Budidaya Ikan Gabus. Yogyakarta: Lily Publisher.

Kovyrshina TB, Rudneva II. 2012. Comparative study of serum albumin level in round goby Neogobius melanostomus form Black Sea and Azov Sea. Int J.Adv. Biol. Res. 2: 203-208.

Kusumaningrum GA. 2014. Uji Kadar albumin dan pertumbuhan ikan gabus (Channa striata) dengan kadar protein pakan yang berbeda. Jurnal Ilmiah Perikanan dan Kelautan 6 (1): 101-105.

Makmur S, Rahardjo MF, Sutrisno Sukimin. 2003. Biologi reproduksi ikan gabus (Channa striato btoch) di daerah banjiran sungai Musi Sumatera Selatan. Jurnal lktiotogi lndonesia 3 (7) : 57-67.

Maulidin R, Muchlisin ZA, Muhammadar A. 2016 Pertumbuhan dan Pemanfaatan Pakan Ikan Gabus (Channa Striata) pada Konsentrasi Enzim Papain yang Berbeda.Jurnal Ilmiah Mahasiswa Kelautan dan Perikanan Unsyiah 1(3): 280-290.

Milinsk MC, Padre RdG, Hayashi C, de Souza NE, Matsushita M. 2003. Influence of diets enriched with different vegetable oils on the fatty acid profiles of snail Helix aspersa maxima. Food Chem. 82(4): 553558.

Muslim. 2007. Jenis-jenis ikan rawa yang bernilai ekonomis pada Rawa Lebak. Jakarta: PT Raja Grafindo Persada.

Muslim. 2012. Perikanan Rawa Lebak Lebung Sumatera Selatan. Palembang: Unsri Press.

Pillay TVR, Kutty MN. 2005. Budidaya:Prinsip dan Praktek. 2 Edn. London: Blackwell Publishing. pp 640.

Primadhani. 2006. Konsumsi energi dan protein pada penderita penyakit hati rawat inap di Perjan RS DR. Cipto Mangunkusumo Jakarta [skripsi]. Bogor: Program Studi Gizi Masyarakat dan Sumberdaya Keluarga, Fakultas Pertanian, Institut Pertanian Bogor.

Rahayu, Maoen AG, Suliantari, Fardias S. 1992. Teknologi fermentasi produk perikanan. Pusat Antar Universitas Institut Pertanian Bogor.

Rohmawati. 2010. Kandungan albumin ikan gabus (Ophiocephalus striatus) berdasarkan berat badan ikan [Skripsi]. Malang. Jurusan Biologi FMIPA Universitas Negeri Malang.

Rukmini. 2013. Pemberia pakan dengan kombinasi berbeda untuk pertumbuhan benih ikan gabus (Channa striata Blkr). Universitas Lembu Mangkurat Fakultas Perikanan Banjarbaru.

Sandjojo H, Hasan H, Dewantoro E. 2014. Pemanfaatan Tepung Keong Mas (Pomacea canalicunata) Sebagai Bahan Subsitusi Tepung Ikan dalam Pakan Terhadap Keragaan Pertumbuhan Ikan Nila Gift (Oreochromis niloticus). Jurnal Ruaya1 (1): 61-70.

Sulistiyati TD. 2010. Pengaruh suhu dan lama pemanasan dengan menggunakan ekstaktor vakum terhadap crude albumin ikan gabus (Ophiocephalus striatus). Protein Jurnal 15 (2): 23-27.

Suprayitno E, Chamidah A, Carvallo JW. 2008. Studi Profil Asam Amino, Albumin pada Ikan Gabus 
68 Sulastri Ilyas et al.

JURNAL SAINS dan INOVASI PERIKANAN / Journal of Fishery Science and Innovation

Vol. 2, No. 2, 60-68, Juli 2018

(Striatus ophiocephalus) dan Ikan Tomang (Ophiocephalus nacropeltes). Malang. Fakultas Perikanan. Universitas Brawijaya.

Syafei DS, Malik BBA, Suherman H, Asnawati. 2005.

Pengenalan jenis-jenis ikan perairan umum. Jambi:

Dinas Perairan Provinsi Jambi.

Watanabe T. 1988. Fish nutrition and mariculture. Department of Aquatic Bioscience. Tokyo: Tokyo University of Fisheries. JICA. 223 pp.

Webster CD, Lim C. 2002. Nutrients requirements and feeding of Finfish for aquaculture. UK: CABI Publishing. $\mathrm{CAB}$ International Wallingford Oxon OX10 8DE. 418p.

Witjaksono HT. 2005. Komposisi kimia ekstrak dan minyak dari lintah laut (Discodoris boholensis) [Tesis]. Bogor. Institut Pertanian Bogor.

Yanti R. 2012. Pengaruh Nutrisi Ikan Gabus Terhadap Penambahan Berat Badan Balita Gizi Kurang [Skripsi]. Riau. Universitas Muhammadiyah Riau.

Yulisman D, Jubaedah, Fitrani M. 2011. Kelangsungan hidup dan pertumbuhan ikan gabus (Channa striata) pada berbagai tingkat pemberian pakan. Jurnal Perikanan dan Kelautan, Universitas Pekalongan. 